\title{
Long-term properties of foamed concrete
}

\author{
Rihards Gailitis ${ }^{1}$, Andina Sprince ${ }^{2}$, Leonids Pakrastins ${ }^{3}$, Genadijs Shakhmenko ${ }^{4}$, \\ Tomass Kozlovskis ${ }^{5}$, Liga Radina ${ }^{6}$ \\ Faculty of Civil Engineering, Riga Technical University, Riga, Latvia \\ E-mail: ${ }^{1}$ rihards.gailitis@edu.rtu.lv (corresponding author)
}

\begin{abstract}
Foamed concrete has been used as a building material since the early 1920s. In the beginning, it was used as an insulation material with very low density. Since then there have been attempts to improve the structural properties in order to increase materials load-bearing capacity. In the present-day foamed concrete is being used in soil reinforcement, manufacturing of building blocks and other sorts of construction materials (Mugahed Amran, Farzadnia, \& Abang Ali, 2015).

The aim of this article is to determine the behaviour and long-term properties of foamed concrete.

Cylindrical specimens $(\varnothing 46 \times 190 \mathrm{~mm})$ were used for creep and shrinkage testing. The creep properties of the specimens were determined by loading them with $20 \%$ and $60 \%$ of the ultimate compressive stress value (Sprince, 2015).

The compressive strength, creep, shrinkage and specific creep of the material were examined. It was determined that during 90 days of creep testing the non-linear creep deformations (specimens loaded with $60 \%$ of the ultimate stress) are 4 times larger than linear creep deformations (specimens loaded with $20 \%$ of the ultimate stress). Also, changes in the modulus of elasticity of foamed concrete were researched over time. Foamed concrete modulus of elasticity reached 12.21 GPa on the 28th day, $12.49 \mathrm{GPa}$ on the $62 \mathrm{nd}$ and $14.23 \mathrm{GPa}$ on the 144 th day since the specimens were made.
\end{abstract}

Keywords: Foamed concrete, long-term properties, creep and shrinkage strains.

\section{Introduction}

Foamed concrete is a cellular cementitious material obtained by introducing foam in the cement matrix. This process gains development of air voids within the specimen microstructure, and thus contributes to obtaining properties such as low self-weight, thermal insulating characteristics, acoustic absorption, increased fire resistance and better workability. It also reduces the strength of the material (Falliano, Domenico, Ricciardi, \& Gugliandolo, 2019; Suleyman Gokce, Hatungimana, \& Ramyar, 2019).

Conventionally foamed concrete has a density of $280-1800 \mathrm{~kg} / \mathrm{m}^{3}$. The density of the cellular (foamed) concrete can be controlled by adding a calculated amount of proper foam into the slurry of water and cement, with and without the addition of aggregate. Foam stability is one of the most important factors for foamed concrete. Unstable foam can cause segregation and uneven density through the material. However, it is relatively difficult to control foam stability because it is affected by many aspects such as foam agent, foam achieving technology, water/cement ratio, and others. Most frequently surfactant, protein, synthetics, metal powders, and hydrogen peroxide are used as foaming-agents (Suleyman et al., 2019; T. T. Nguyen, Bui, Ngo, G. D. Nguyen, \& Kreher, 2019; S. Ghorbani, S. Ghorbani, Tao, de Brito, \& Tavakkolizadeh, 2019; Li, Wang, Zhou, He, \& Huang, 2019).

It has been recognized that the compressive strength of foamed concrete decreases as the porosity increases. Because the mechanical properties of the material are greatly affected by its pore structure, its void features are deliberately considered in many studies (T. T. Nguyen, Bui, Ngo, \& G. D. Nguyen, 2017).

A common strategy to increase the strength of lightweight foamed concrete (without worsening the characteristics associated with low densities) is the inclusion of various kinds of fibers that are embedded in the cementitious matrix (Falliano et al., 2019).

Creep is an important phenomenon of concrete since it affects the deformation and stress distribution within concrete structures. The investigations on concrete creep have lasted for over a hundred years and the findings are considerable. It has been reported that the factors affecting concrete creep include mixture proportion, curing age, environmental temperature, relative humidity, and applied stress level (Liang \& Wey, 2019; Neville, 2002). 


\section{Materials and methods}

Foamed concrete mix was prepared according to the composition shown in Table 1.

Table 1. Foamed concrete mix

\begin{tabular}{|l|c|c|}
\hline \multicolumn{1}{|c|}{ Ingredients } & Units & Volume \\
\hline Cement CEM I 42.5N & $\mathrm{kg} / \mathrm{m}^{3}$ & 240 \\
\hline Quartz sand 0/0.5 mm & $\mathrm{kg} / \mathrm{m}^{3}$ & 300 \\
\hline Foam agent (Tukums) mixed together with $0.351 \mathrm{H}_{2} \mathrm{O}$ & $\mathrm{kg} / \mathrm{m}^{3}$ & 1.05 \\
\hline PP fibers & $\mathrm{kg} / \mathrm{m}^{3}$ & 0.3 \\
\hline Micro silica Elkem 971 U & $\mathrm{kg} / \mathrm{m}^{3}$ & 8 \\
\hline Water & $\mathrm{kg} / \mathrm{m}^{3}$ & 80 \\
\hline Plastificator Stachema & $\mathrm{kg} / \mathrm{m}^{3}$ & 3.098 \\
\hline W/C & - & 0.333 \\
\hline
\end{tabular}
1998).

For foamed concrete creep testing cylindrical specimens $(\varnothing 46 \times 190 \mathrm{~mm})$ were prepared (RILEM TC 107-CSP,

The compressive strength was determined according to EN 12390-3:2009. A compression machine with the accuracy of $\pm 1 \%$ was used and the rate of loading was $0.7 \mathrm{MPa} / \mathrm{sec}$. Compression tests were performed on specimens 28 and 144 days after specimens were made. For compressive strength testing cylindrical specimens $(\varnothing 46 \times 95 \mathrm{~mm}) \mathrm{were}$ prepared (see Figure 1).

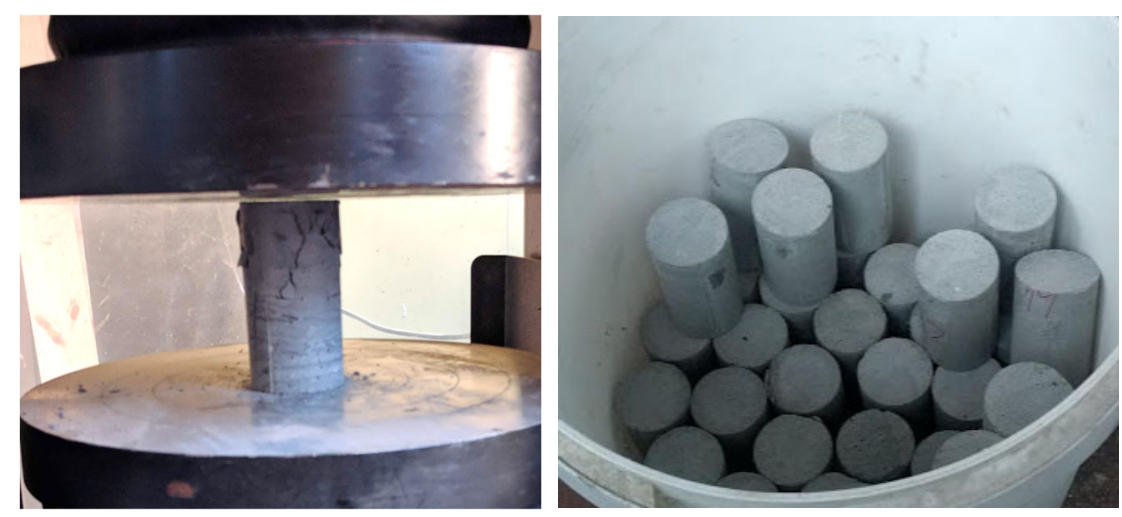

Figure 1. Determination of compressive strength values

For creep and shrinkage deformation tests, 6 aluminium plates $(10 \times 15 \mathrm{~mm})$ were glued to each specimen in pairs. Afterwards, strain gauges were attached to those plates (see Figure 2).

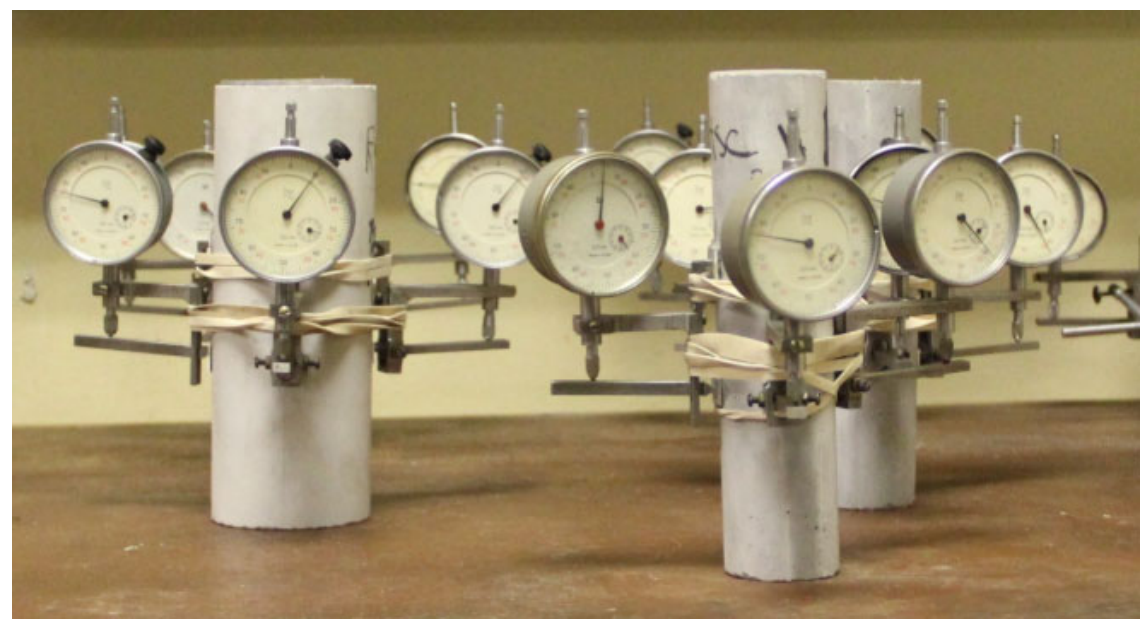

Figure 2. Prepared samples for shrinkage and creep tests 
The creep was monitored and measured for foamed concrete specimens that were subjected to a uniform compressive load. The level of applied load was constant through all the creep testing period.

During creep tests, specimens were loaded with a load equivalent to $20 \%$ and $60 \%$ of the ultimate compressive strength, which was determined in compressive strength tests. Specimens were loaded gradually by $25 \%$ of a determined load in a short period of time (within 5 minutes). Specimens were kept under constant load for 93 days and tests for modulus of elasticity were done every 5 days for 125 days. Some specimens from linear and non-linear creep testing were kept loaded for 144 days.

Specimens were loaded in creep lever test stands designed especially for creep tests (see Figure 3).
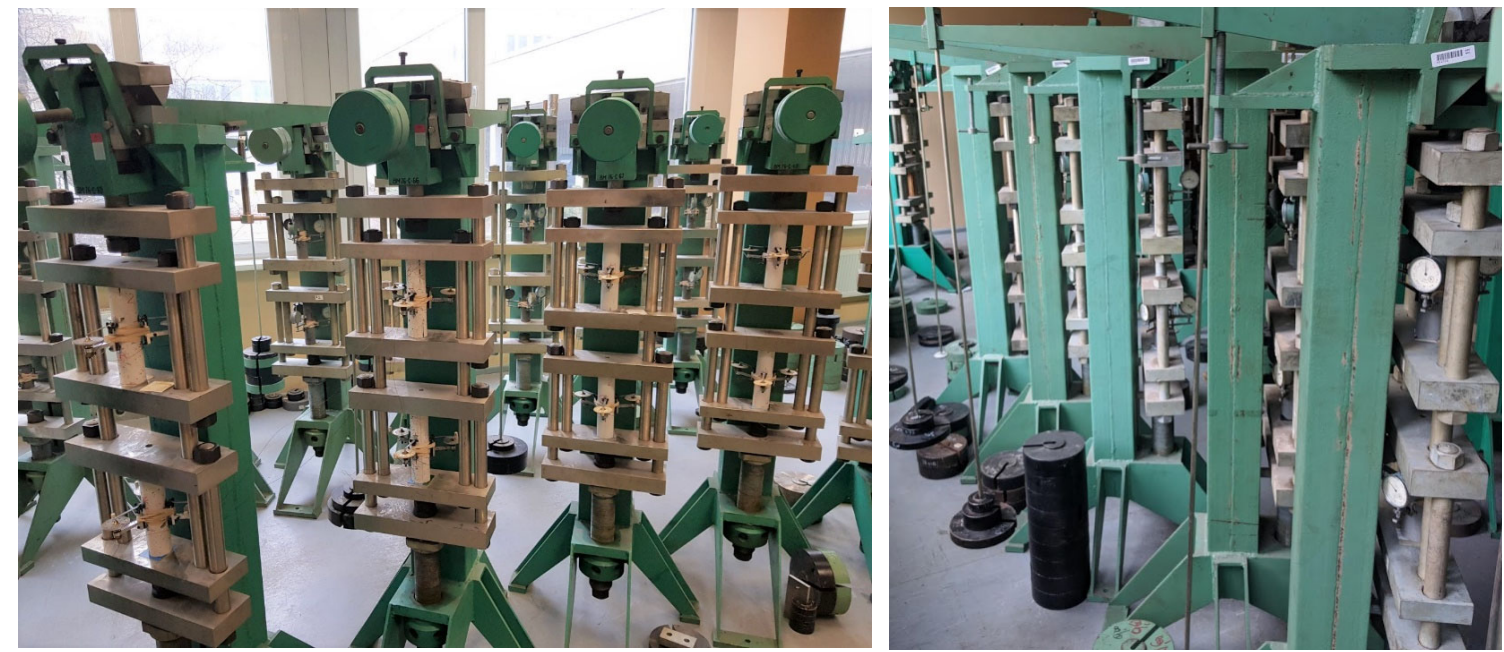

Figure 3. Specimens on creep test lever stands

During creep tests also shrinkage and modulus of elasticity for foamed concrete specimens were determined. Shrinkage deformations were monitored for 144 days. Modulus of elasticity was tested every 5 days (loading and unloading of the specimens were done). After each loading step, the reading of deformations was made and afterward modulus of elasticity was calculated (Sprince, 2015).

After the creep and shrinkage deformation test, specimens were cut in half. Half of the specimens were placed in water for 24 hours for determination of their water absorption (see Figure 4).
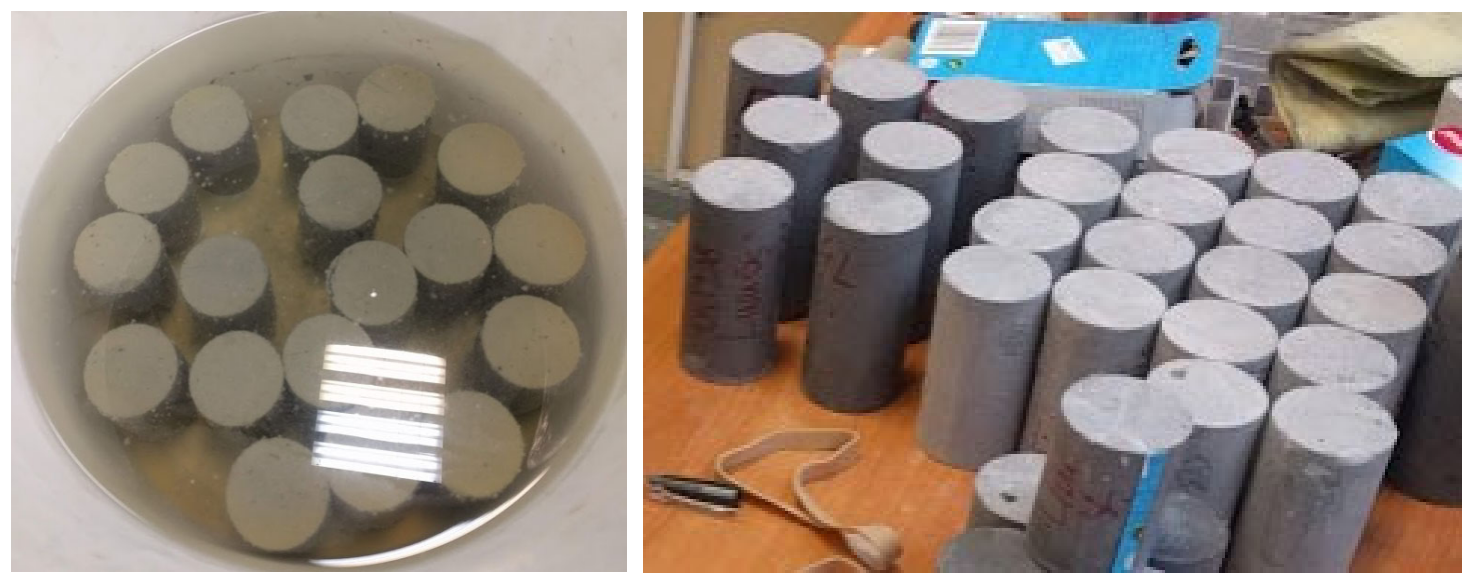

Figure 4. Water saturated and air-dry foam concrete specimens

Afterward water absorption of speciments were measured (see Table 2) and subsequently the compressive strength value was determined for all specimens, depending on whether they have been loaded or/and soaked with water or not.

\section{Results and discussion}

Water absorption of all specimens is shown in Table 2. 
Table 2. Water absorption of specimens

\begin{tabular}{|c|c|c|c|c|c|c|c|c|}
\hline \multirow[b]{2}{*}{ Specimen type } & \multirow{2}{*}{$\begin{array}{l}\text { Specimen } \\
\text { mark }\end{array}$} & \multicolumn{2}{|c|}{ Specimen size } & \multirow{2}{*}{$\begin{array}{l}\text { Weight } \\
\text { before } \\
\mathrm{H}_{2} \mathrm{O}, \mathrm{kg}\end{array}$} & \multirow{2}{*}{$\begin{array}{l}\text { Weight } \\
\text { after } \\
\mathrm{H}_{2} \mathrm{O}, \mathrm{kg}\end{array}$} & \multirow{2}{*}{$\begin{array}{c}\text { Weight after } \\
1 \text { hour out of } \\
\mathrm{H}_{2} \mathrm{O}, \mathrm{kg}\end{array}$} & \multirow{2}{*}{$\begin{array}{l}\text { Absorbed } \\
\quad \mathrm{H}_{2} \mathrm{O} \\
\text { weight, kg }\end{array}$} & \multirow{2}{*}{$\begin{array}{l}\text { Lost mois- } \\
\text { ture in } \\
1 \text { hour, kg }\end{array}$} \\
\hline & & $\begin{array}{l}\text { Diameter, } \\
\mathrm{mm}\end{array}$ & $\begin{array}{l}\text { Height, } \\
\mathrm{mm}\end{array}$ & & & & & \\
\hline \multirow{4}{*}{$\begin{array}{l}\text { Modulus of elas- } \\
\text { ticity }\end{array}$} & 12.1 & 46.00 & 90.10 & 0.1790 & 0.1995 & 0.1990 & 0.0205 & 0.0005 \\
\hline & 25.1 & 46.00 & 89.52 & 0.1770 & 0.1955 & 0.1945 & 0.0185 & 0.0010 \\
\hline & 16.1 & 46.00 & 89.44 & 0.1730 & 0.1920 & 0.1915 & 0.0190 & 0.0005 \\
\hline & 14.1 & 46.00 & 89.00 & 0.1780 & 0.1975 & 0.1970 & 0.0195 & 0.0005 \\
\hline \multirow{4}{*}{ Shrinkage } & 23.1 & 46.00 & 89.34 & 0.1760 & 0.1960 & 0.1950 & 0.0200 & 0.0010 \\
\hline & 18.1 & 46.00 & 89.52 & 0.1760 & 0.1955 & 0.1945 & 0.0195 & 0.0010 \\
\hline & 10.1 & 46.00 & 89.44 & 0.1755 & 0.1955 & 0.1945 & 0.0200 & 0.0010 \\
\hline & 19.1 & 46.00 & 88.74 & 0.1775 & 0.1975 & 0.1970 & 0.0200 & 0.0005 \\
\hline \multirow{6}{*}{$\begin{array}{l}\text { Linear creep } \\
\text { (specimen loaded } \\
\text { with } 20 \% \text { of ulti- } \\
\text { mate strength) }\end{array}$} & 8.1 & 46.00 & 89.34 & 0.1745 & 0.1940 & 0.1935 & 0.0195 & 0.0005 \\
\hline & 24.1 & 46.00 & 89.26 & 0.1750 & 0.1940 & 0.1930 & 0.0190 & 0.0010 \\
\hline & 9.1 & 46.00 & 89.50 & 0.1780 & 0.1980 & 0.1970 & 0.0200 & 0.0010 \\
\hline & 15.1 & 46.00 & 89.22 & 0.1785 & 0.1990 & 0.1980 & 0.0205 & 0.0010 \\
\hline & 21.1 & 46.00 & 89.52 & 0.1760 & 0.1945 & 0.1940 & 0.0185 & 0.0005 \\
\hline & 3.1 & 46.00 & 89.46 & 0.1780 & 0.1970 & 0.1965 & 0.0190 & 0.0005 \\
\hline \multirow{4}{*}{$\begin{array}{l}\text { Non-linear creep } \\
\text { (specimen loaded } \\
\text { with } 60 \% \text { of ulti- } \\
\text { mate strength) }\end{array}$} & 17.1 & 46.00 & 89.46 & 0.1765 & 0.1960 & 0.1955 & 0.0195 & 0.0005 \\
\hline & 22.1 & 46.00 & 89.48 & 0.1760 & 0.1980 & 0.1965 & 0.0220 & 0.0015 \\
\hline & 11.1 & 46.00 & 89.00 & 0.1765 & 0.1965 & 0.1960 & 0.0200 & 0.0005 \\
\hline & 4.1 & 46.00 & 90.20 & 0.1800 & 0.1995 & 0.1990 & 0.0195 & 0.0005 \\
\hline
\end{tabular}

As it is visible from Table 2 the largest water absorption is for specimens that have been in a non-linear creep test. All the remaining test specimens have got relatively close absorbed water amount. On average "Modulus of elasticity" specimens have 0.0194 g, "Shrinkage" specimens - 0.0199 g, "Linear creep" specimens - 0.0194 g and "Nonlinear creep" specimens $-0.0203 \mathrm{~g}$ of absorbed water. Absorbed water loss in 1 hour is similar among all the samples and their average amounts are similar.

Foamed concrete specimen's compressive strength values after 28 days are shown in Table 3.

Table 3. The compressive strength of 28 days old specimens

\begin{tabular}{|c|c|c|c|c|c|c|}
\hline \multirow{2}{*}{$\begin{array}{c}\text { Specimen } \\
\text { mark }\end{array}$} & \multirow{2}{*}{$\begin{array}{c}\text { Specimen } \\
\text { number }\end{array}$} & $\begin{array}{c}\text { Diameter, } \\
\mathrm{mm}\end{array}$ & $\begin{array}{c}\text { Height, } \\
\mathrm{mm}\end{array}$ & $\begin{array}{c}\text { Specimen } \\
\text { weight, } \\
\mathrm{kg}\end{array}$ & $\begin{array}{c}\text { Compressive } \\
\text { load, } \\
\mathrm{kN}\end{array}$ & $\begin{array}{c}\text { Compressive } \\
\text { strength, } \\
\mathrm{MPa}\end{array}$ \\
\hline 1 & 1 & 46.00 & 93.00 & 0.1965 & 12.5 & 7.525 \\
\hline 1 & 2 & 46.00 & 93.00 & 0.2005 & 13.0 & 7.826 \\
\hline 2 & 1 & 46.00 & 94.00 & 0.1980 & 14.5 & 8.729 \\
\hline 2 & 2 & 46.00 & 94.00 & 0.2020 & 14.0 & 8.428 \\
\hline 5 & 1 & 46.00 & 93.00 & 0.2005 & 13.5 & 8.127 \\
\hline 5 & 2 & 46.00 & 93.00 & 0.2020 & 14.8 & 8.910 \\
\hline 6 & 1 & 46.00 & 95.00 & 0.1940 & 13.8 & 8.308 \\
\hline 6 & 2 & 46.00 & 95.00 & 0.1970 & 14.4 & 8.669 \\
\hline
\end{tabular}

Average compressive strength for foamed concrete specimens is $8.32 \mathrm{MPa}$.

Total creep and shrinkage deformations are given in Figure 5. 


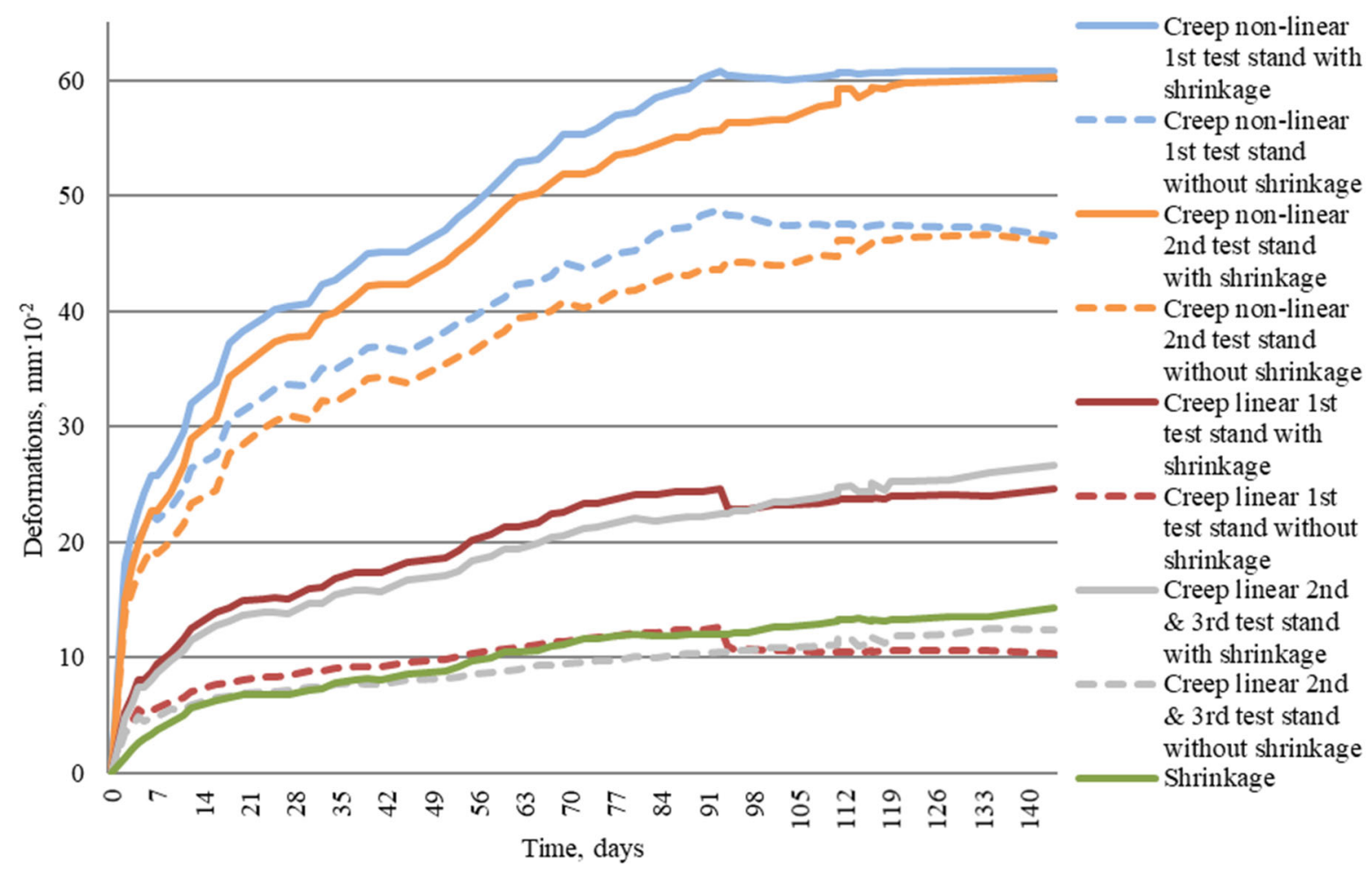

Figure 5. Linear, non-linear and shrinkage deformations of foamed concrete

During creep tests also modulus of elasticity for foamed concrete specimens was determined. Every 5 days (loading and unloading of specimens were done). Calculated modulus of elasticity development is shown in Figure 6.

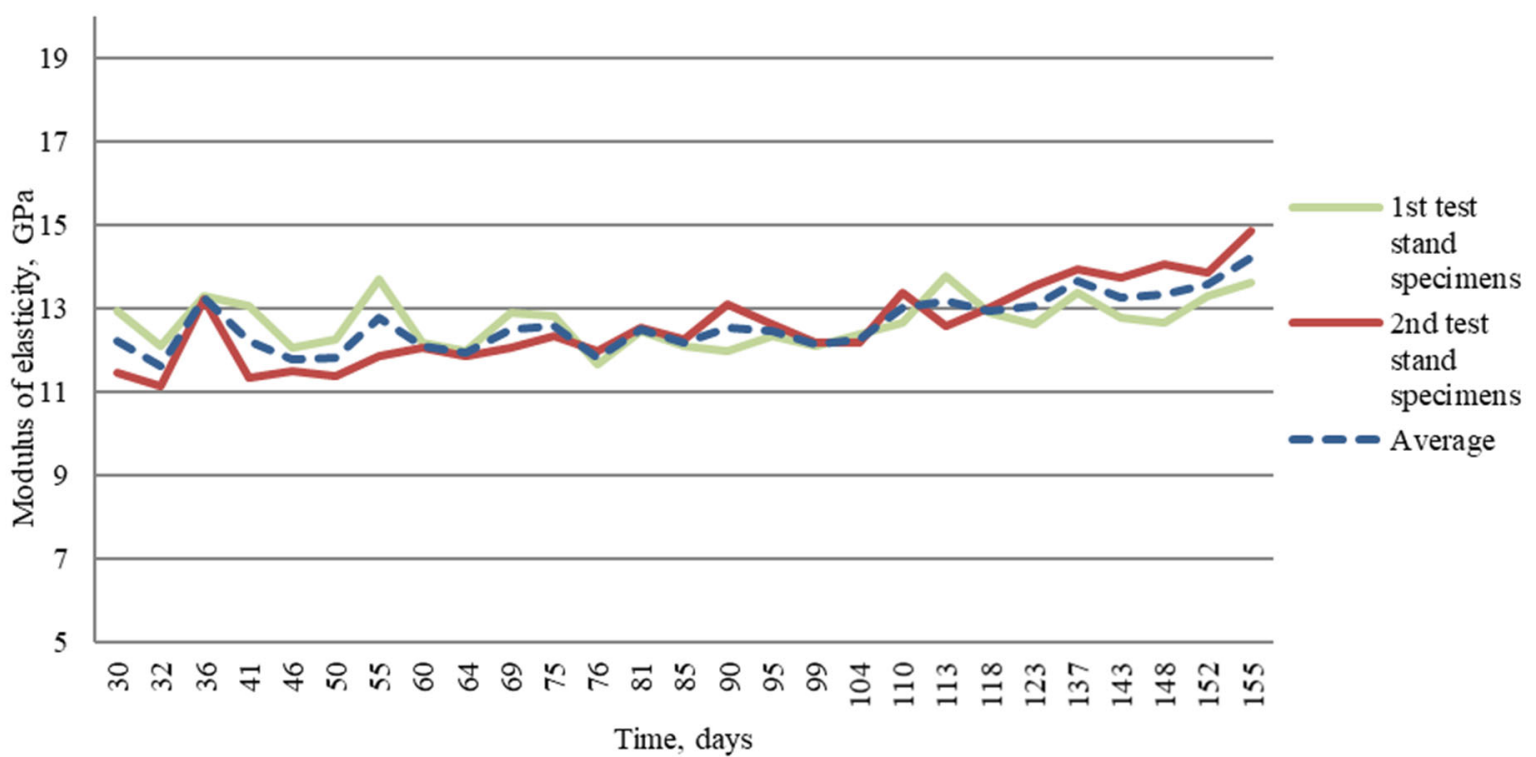

Figure 6. Modulus of elasticity during creep test

From Figure 5 it can be determined that deformation amount of non-linear creep specimens is significantly larger than of linear creep specimens. The difference of deformations between linear and non-linear creep specimens reaches 2.5 times at the end of testing. It also should be mentioned that creep deformations have a large impact on combined deformations. About a half of linear creep deformations measured on test stand actually is shrinkage deformation. For non-linear creep specimens, the shrinkage is about $40 \%$ of all deformation recorded on test stands.

After creep and shrinkage tests, all specimens were used for compression tests. Results and difference between water saturated foamed concrete and air-dry foamed concrete are shown in Table 4 and Table 5 and Figure 7. 
Gailitis, R.; Sprince, A.; Pakrastins, L.; Shakhmenko, G.; Kozlovskis, T.; Radina, L. 2019. Long-term properties of foamed concrete

Table 4. Water saturated 172 days old specimen compressive strength

\begin{tabular}{|c|c|c|c|c|c|c|c|}
\hline \multirow{2}{*}{$\begin{array}{l}\text { Specimen } \\
\text { type }\end{array}$} & \multirow{2}{*}{$\begin{array}{l}\text { Specimen } \\
\text { mark }\end{array}$} & \multicolumn{2}{|c|}{ Specimen size } & \multirow{2}{*}{$\begin{array}{l}\text { Weight, } \\
\text { kg }\end{array}$} & \multirow{2}{*}{$\begin{array}{c}\text { Compressive } \\
\text { load, kN }\end{array}$} & \multirow{2}{*}{$\begin{array}{l}\text { Compressive } \\
\text { strength, } \mathrm{MPa}\end{array}$} & \multirow{2}{*}{$\begin{array}{c}\text { Average } \\
\text { compressive } \\
\text { strength, } \mathrm{MPa}\end{array}$} \\
\hline & & $\begin{array}{l}\text { Diameter, } \\
\mathrm{mm}\end{array}$ & $\begin{array}{l}\text { Height, } \\
\text { mm }\end{array}$ & & & & \\
\hline \multirow{4}{*}{$\begin{array}{l}\text { Modulus of } \\
\text { elasticity }\end{array}$} & 12.1 & 46.00 & 90.10 & 0.1990 & 10.9 & 6.562 & \multirow{4}{*}{7.149} \\
\hline & 25.1 & 46.00 & 89.52 & 0.1945 & 14.3 & 8.609 & \\
\hline & 16.1 & 46.00 & 89.44 & 0.1915 & 11.3 & 6.803 & \\
\hline & 14.1 & 46.00 & 89.00 & 0.1970 & 11.0 & 6.622 & \\
\hline \multirow{4}{*}{ Shrinkage } & 23.1 & 46.00 & 89.34 & 0.1950 & 13.3 & 8.007 & \multirow{4}{*}{7.811} \\
\hline & 18.1 & 46.00 & 89.52 & 0.1945 & 11.6 & 6.983 & \\
\hline & 10.1 & 46.00 & 89.44 & 0.1945 & 13.4 & 8.067 & \\
\hline & 19.1 & 46.00 & 88.74 & 0.1970 & 13.6 & 8.188 & \\
\hline \multirow{6}{*}{$\begin{array}{l}\text { Linear creep } \\
\text { (specimen } \\
\text { loaded with } \\
20 \% \text { of ultimate } \\
\text { load) }\end{array}$} & 8.1 & 46.00 & 89.34 & 0.1935 & 11.2 & 6.743 & \multirow{6}{*}{8.000} \\
\hline & 24.1 & 46.00 & 89.26 & 0.1930 & 14.1 & 8.489 & \\
\hline & 9.1 & 46.00 & 89.50 & 0.1970 & 12.2 & 7.345 & \\
\hline & 15.1 & 46.00 & 89.22 & 0.1980 & 13.8 & 8.308 & \\
\hline & 21.1 & 46.00 & 89.52 & 0.1940 & 13.6 & 8.188 & \\
\hline & 3.1 & 46.00 & 89.46 & 0.1965 & 14.9 & 8.970 & \\
\hline \multirow{4}{*}{$\begin{array}{l}\text { Non-linear } \\
\text { creep (specimen } \\
\text { loaded with } \\
60 \% \text { of ultimate } \\
\text { load) }\end{array}$} & 17.1 & 46.00 & 89.46 & 0.1955 & 13.3 & 8.007 & \multirow{4}{*}{6.938} \\
\hline & 22.1 & 46.00 & 89.48 & 0.1965 & 10.3 & 6.201 & \\
\hline & 11.1 & 46.00 & 89.00 & 0.1960 & 11.4 & 6.863 & \\
\hline & 4.1 & 46.00 & 90.20 & 0.1990 & 11.1 & 6.682 & \\
\hline
\end{tabular}

Table 5. Air dry 172 days old specimen compressive strength

\begin{tabular}{|c|c|c|c|c|c|c|c|}
\hline \multirow[b]{2}{*}{$\begin{array}{l}\text { Specimen } \\
\text { type }\end{array}$} & \multirow[b]{2}{*}{$\begin{array}{l}\text { Specimen } \\
\text { mark }\end{array}$} & \multicolumn{2}{|c|}{ Specimen size } & \multirow[b]{2}{*}{$\begin{array}{l}\text { Weight, } \\
\text { kg }\end{array}$} & \multirow[b]{2}{*}{$\begin{array}{c}\text { Compressive } \\
\text { load, } \mathrm{kN}\end{array}$} & \multirow[b]{2}{*}{$\begin{array}{l}\text { Compressive } \\
\text { strength, } \mathrm{MPa}\end{array}$} & \multirow{2}{*}{$\begin{array}{c}\text { Average } \\
\text { compressive } \\
\text { strength, MPa }\end{array}$} \\
\hline & & $\begin{array}{l}\text { Diameter, } \\
\mathrm{mm}\end{array}$ & $\begin{array}{c}\text { Height, } \\
\mathrm{mm}\end{array}$ & & & & \\
\hline \multirow{4}{*}{$\begin{array}{l}\text { Modulus of } \\
\text { elasticity }\end{array}$} & 12.2 & 46.00 & 89.24 & 0.1780 & 16.6 & 9.994 & \multirow{4}{*}{9.301} \\
\hline & 25.2 & 46.00 & 89.22 & 0.1765 & 15.2 & 9.151 & \\
\hline & 16.2 & 46.00 & 89.20 & 0.1740 & 15.9 & 9.572 & \\
\hline & 14.2 & 46.00 & 89.60 & 0.1780 & 14.1 & 8.489 & \\
\hline \multirow{4}{*}{ Shrinkage } & 23.2 & 46.00 & 89.22 & 0.1770 & 17.6 & 10.596 & \multirow{4}{*}{10.054} \\
\hline & 18.2 & 46.00 & 89.64 & 0.1755 & 15.0 & 9.030 & \\
\hline & 10.2 & 46.00 & 89.50 & 0.1760 & 18.0 & 10.836 & \\
\hline & 19.2 & 46.00 & 89.38 & 0.1790 & 16.2 & 9.753 & \\
\hline \multirow{6}{*}{$\begin{array}{l}\text { Linear creep } \\
\text { (specimen } \\
\text { loaded with } \\
20 \% \text { of ultimate } \\
\text { load) }\end{array}$} & 8.2 & 46.00 & 89.50 & 0.1735 & 13.2 & 7.947 & \multirow{6}{*}{9.900} \\
\hline & 24.2 & 46.00 & 89.60 & 0.1770 & 19.8 & 11.920 & \\
\hline & 9.2 & 46.00 & 89.24 & 0.1795 & 18.9 & 11.378 & \\
\hline & 15.2 & 46.00 & 89.44 & 0.1775 & 14.7 & 8.850 & \\
\hline & 21.2 & 46.00 & 89.50 & 0.1745 & 15.2 & 9.151 & \\
\hline & 3.2 & 46.00 & 89.24 & 0.1760 & 16.7 & 10.054 & \\
\hline \multirow{4}{*}{$\begin{array}{l}\text { Non-linear } \\
\text { creep (specimen } \\
\text { loaded with } \\
60 \% \text { of ultimate } \\
\text { load) }\end{array}$} & 17.2 & 46.00 & 89.50 & 0.1750 & 15.1 & 9.091 & \multirow{4}{*}{9.768} \\
\hline & 22.2 & 46.00 & 88.70 & 0.1740 & 15.4 & 9.271 & \\
\hline & 11.2 & 46.00 & 89.44 & 0.1790 & 19.4 & 11.679 & \\
\hline & 4.2 & 46.00 & 89.22 & 0.1795 & 15.0 & 9.030 & \\
\hline
\end{tabular}




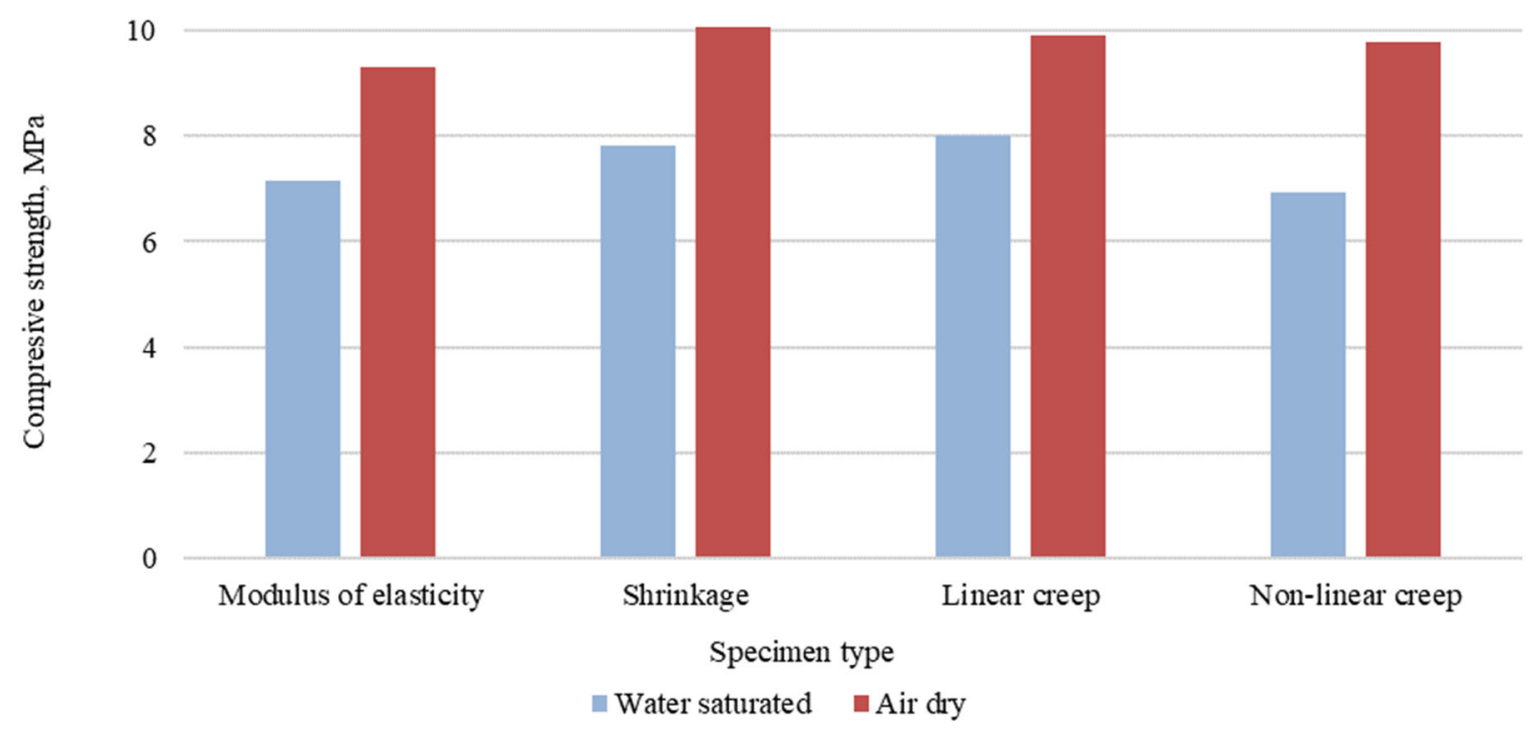

Figure 7. Compressive strength difference for 172 days old specimens

From Table 4 and Table 5 and Figure 7 it can be deduced that all tested specimens have a significant decrease in compressive strength due to water absorption. But it also should be considered that the biggest impact is on non-linear creep specimens. For these specimens, the compressive strength has decreased by $29 \%$ while the compressive strength of the linear creep specimens decreased by $19 \%$.

Compressive strength difference between specimens at the beginning of creep and shrinkage tests is shown in Figure 8.

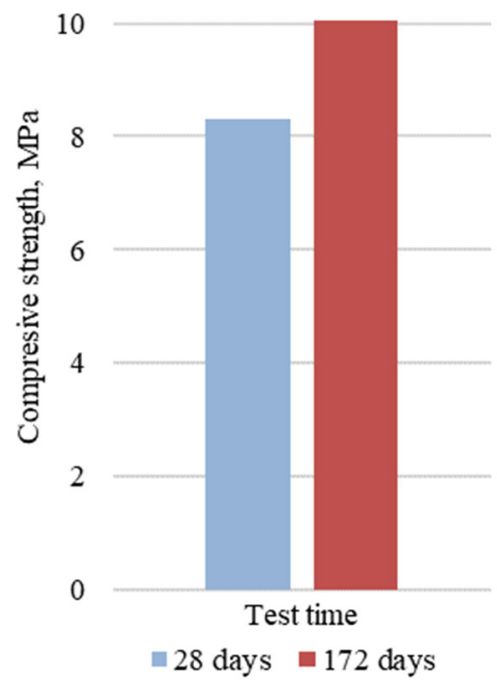

Figure 8. Compressive strength difference before and after creep test

During the 144 days specimen compressive strength has increased by $17 \%$ or in other terms from $8.315 \mathrm{MPa}$ on 28 th day to $10.054 \mathrm{MPa}$ on the $172 \mathrm{nd}$ day. This compressive strength increase for specimens has been measured only for air-dry specimens. 


\section{Conclusions}

The long-term properties of foamed concrete were measured over 144 days time period by performing creep and shrinkage tests, compressive strength and modulus of elasticity experiments. According to obtained results, the following conclusions are made:

1. Air-dry foamed concrete has a higher compressive strength. The loss of compressive strength of water saturated specimens is from $19 \%$ (creep specimens that have been loaded with $20 \%$ of ultimate strength) to $29 \%$ (creep specimens that have been loaded with $60 \%$ of ultimate stress value).

2. After curing of 28 days foamed concrete still increases its modulus of elasticity relatively rapidly in contrast to regular Portland cement concrete. In 144 test days, foamed concrete specimens have increased their modulus of elasticity from $12.21 \mathrm{GPa}$ to $14.23 \mathrm{GPa}$ which is a $14.1 \%$ increase in modulus of elasticity.

3. The compressive strength of not-loaded specimens during 144-day testing has increased by $17.3 \%$.

4. Linear and non-linear creep tests show, that elastic deformation when specimens are unloaded on the 93rd day for linear creep specimens are relatively bigger than for non-linear specimens. The elastic deformation difference between linear and non-linear creep specimens on the day they were unloaded was $25 \%$ and after 10 days since the specimens were unloaded it dropped down to $15 \%$. The elastic deformation for specimens on the unloading day was $1.30 \cdot 10^{-2} \mathrm{~mm}$ for non-linear creep specimens and $1.73 \cdot 10^{-2} \mathrm{~mm}$ for linear creep specimens. After 10 days the deformations were $1.60 \cdot 10^{-2} \mathrm{~mm}$ for non-linear creep specimens and $1.88 \cdot 10^{-2} \mathrm{~mm}$ for linear creep specimens.

5. During the shrinkage test, specimens showed a significant amount of shrinkage deformations. All in all, in 144 days specimens on average shrank for $14.27 \cdot 10^{-2} \mathrm{~mm}$.

\section{Acknowledgements}

This research is funded by the Latvian Council of Science, project [Long-term properties of innovative cement composites in various stress-strain conditions] project No. lzp-2018/2-0249.

\section{References}

Falliano, D., Domenico, D. D., Ricciardi, G., \& Gugliandolo, E. (2019). Compressive and flexural strength of fiber-reinforced foamed concrete: Effect of fiber content, curing conditions and dry density. Construction and Building Materials, 198, 479493. https://doi.org/10.1016/j.conbuildmat.2018.11.197

Ghorbani, S., Ghorbani, S., Tao, Z., Brito, J. de, \& Tavakkolizadeh, M. (2019). Effect of magnetized water on foam stability and compressive strength of foam concrete. Construction and Building Materials, 197, 280-290. https://doi.org/10.1016/j.conbuildmat.2018.11.160

Li, T., Wang, Z., Zhou, T., He, Y., \& Huang, F. (2019). Preperation and properties of magnesium phosphate cement foam concrete with $\mathrm{H} 2 \mathrm{O} 2$ as foaming agent. Construction and Building Materials, 205, 566-573. https://doi.org/10.1016/j.conbuildmat.2019.02.022

Liang, S., \& Wei, Y. (2019). Methodology of obtaining intrinsic creep property of concrete by flexural deflection test. Cement and Concrete Composites, 97, 288-299. https://doi.org/10.1016/j.cemconcomp.2019.01.003

Mugahed Amran, Y. H., Farzadnia, N., \& Abang Ali, A. A. (2015). Properties and applications of foamed concrete; a review. Construction and Building Materials, 101, 990-1005. https://doi.org/10.1016/j.conbuildmat.2015.10.112

Neville, A. M. (2002). Creep of concrete and behaviour of structures. Concrete International, 5, 52-55.

Nguyen, T. T., Bui, H. H., Ngo, T. D., \& Nguyen, G. D. (2017). Experimental and numerical investigation of influence of air-voids on the compressive behaviour of foamed concrete. Materials \& Design, 130, 103-119. https://doi.org/10.1016/j.matdes.2017.05.054

Nguyen, T. T., Bui, H. H., Ngo, T. D., Nguyen, G. D., \& Kreher, M. U. (2019). A micromechanical investigation for the effects of pore size and its distribution on geopolymer foam concrete under uniaxial ceompression. Engineering Fracture Mechanics, 209, 228-244. https://doi.org/10.1016/j.engfracmech.2019.01.033

RILEM TC 107-CSP. (1998). Creep and shrinkage prediction models: principles of their formation. Measurement of time-dependent strains of concrete. Materials and Structures/Matériaux et Constructions, 31(8), 507-512. https://doi.org/10.1007/BF02481530

Sprince, A. (2015). Methodology for determination of long - term properties and crack development research in extra fine aggregate cement composites (PhD Thesis). Riga, Riga Technical University (RTU). https://doi.org/10.17770/etr2015vol1.199

Suleyman Gokce, H., Hatungimana, D., \& Ramyar, K. (2019). Effect of fly ash and silica fume on hardened properties of foam concrete. Construction and Building Materials, 194, 1-11. https://doi.org/10.1016/j.conbuildmat.2018.11.036 